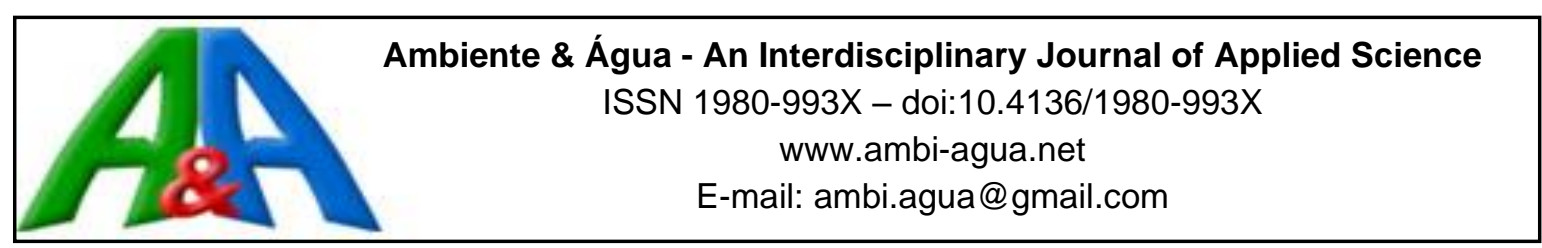

\title{
Chemical attributes of soil irrigated with treated sewage effluent and cultivated with bell pepper
}

\author{
ARTICLES doi:10.4136/ambi-agua.2341
}

Received: 11 Oct. 2018; Accepted: 19 Jul. 2019

\section{Waltoíres Reis da Silva Júnior ${ }^{1}$; Delvio Sandri ${ }^{1 *}$; Cícero Célio de Figueiredo ${ }^{1 D}$; Rodrigo Moura Pereira ${ }^{1}$}

\author{
${ }^{1}$ Faculdade de Agronomia e Medicina Veterinária (FAV), Universidade de Brasília (UNB). \\ Campus Darcy Ribeiro, ICC Sul, S/N, CEP 70910-900, Brasília, DF, Brazil. \\ E-mail: waltoires@gmail.com, cicerocf@unb.br, rodrigomouracbs@gmail.com \\ *Corresponding author. E-mail: sandri@unb.br
}

\begin{abstract}
The use of treated sewage effluents (TSE) for irrigation purposes is a viable alternative for wastewater reuse and nutrient supply to the soil, which represent the two main environmental benefits. This work therefore evaluated the effect of the application of TSE on the quantity of nutrients added to the soil and changes in the chemical attributes of a Red-Yellow Latosol in the layer from 0.0 to $0.2 \mathrm{~m}$ cultivated with the bell pepper F1 Canary hybrid and surface drip irrigated. The experiment was carried out under field conditions from September 2015 to January 2016 in a randomized block statistical design with four replications, including the following treatments: river water, TSE, river water with base fertilization, TSE with base fertilization, TSE with cover fertilization, and TSE with cover and base fertilization. Irrigation of the bell pepper cultivation with TSE increased the level of potassium but did not affect the levels of phosphorus, organic matter and $\mathrm{pH}$ of the soil at the end of the growing cycle. The following amounts of nutrients were added to the soil by irrigation with TSE: $10 \mathrm{~kg} \mathrm{ha}^{-1}$ of total nitrogen, $10 \mathrm{~kg} \mathrm{ha}^{-1}$ of total potassium and $0.5 \mathrm{~kg} \mathrm{ha}^{-1}$ of total phosphate. In general, TSE induced greater productivity of the peppers than those irrigated with river water, even when including mineral fertilization.
\end{abstract}

Keywords: soil nutrients, wastewater reuse, water quality.

\section{Atributos químicos do solo irrigado com efluente de esgoto tratado e cultivado com pimentão}

\section{RESUMO}

$\mathrm{O}$ uso de efluentes de esgoto tratado (EET) para fins de irrigação se destaca pelo reaproveitamento da água e pelo aporte de nutrientes ao solo, representando os dois principais benefícios ambientais. Assim, o objetivo deste trabalho foi avaliar o efeito da aplicação de EET sobre a quantidade de nutriente adicionado ao solo e alteração nos atributos químicos de um Latossolo Vermelho Amarelo na camada de 0,0 a 0,2 m, sob cultivo de pimentão, híbrido Canário F1, irrigado por gotejamento superficial. O experimento foi desenvolvido em condições de campo no período de setembro de 2015 a janeiro de 2016. O delineamento estatístico foi em blocos casualizados, com quatro repetições, com os seguintes tratamentos: 
água de córrego, EET, água de córrego com adubação de base, EET com adubação de base, EET com adubação de cobertura e EET com adubação de cobertura e de base, com quatro repetições. A irrigação com EET no cultivo de pimentão aumentou os teores de potássio, mas não afetou os teores de fósforo, matéria orgânica e o pH do solo ao final do ciclo de cultivo. Foram adicionados ao solo, por meio de irrigação com EET, $10 \mathrm{~kg} \mathrm{ha}^{-1}$ de nitrogênio total, $10 \mathrm{~kg} \mathrm{ha}^{-1}$ de potássio total e $0,5 \mathrm{~kg} \mathrm{ha}^{-1}$ de fosfato total. De maneira geral, a aplicação de EET promoveu maior produtividade de pimentão do que o uso de água de córrego, mesmo sob complementação de adubação mineral.

Palavras-chave: nutrientes no solo, qualidade da água, reúso de água.

\section{INTRODUCTION}

With the growing awareness that water is a limited natural resource and has significant economic value, sustainable and rational use techniques are being increasingly implemented, including the use of treated sewage effluents (TSE), which is important in many regions, as in the Federal District, Brazil. Oliveira et al. (2016) pointed out that irrigation with TSE is a promising practice in areas facing water scarcity and pollution of water resources by the release of untreated sewage. At the same time, the scarcity of freshwater in semi-arid regions generates social and environmental impacts, which is likely to be intensified in the coming years due to high rates of population growth and increased water demand by the agricultural sector (Bedbabis et al., 2014).

According to Sapkota (2019), climate change and population growth are contributing to a growing global freshwater crisis that is exacerbating agricultural water scarcity and compromising food security and public health. In light of these challenges, the increased reliance on nontraditional irrigation water sources, such as reclaimed or recycled water, is emerging as a potentially viable strategy to address water and food insecurity worldwide.

Thus, according to Rahav et al. (2017), there is a clear expansion of the use of treated effluents (TSEs) as an alternative resource in regions with fresh water shortage. In Israel, for example, most orchards are irrigated with TSE, and although the benefits to irrigation are apparent, there is evidence of its cumulative negative effects on soil, plants and productivity. However, the study of the movement of salts and metals in the soil is complex and is subject to multifactorial effects as well as to the soil physical-chemical properties. In view of this, additional studies are necessary to understand salt and nutrient concentrations influence on relationships with plants (Papaioannou et al., 2018). Although agricultural irrigation is an important destination for the TSE, its management must be environmentally sustainable (Musazura et al., 2019).

Effluents generally contain several types of salts that originate from houses, restaurants, etc., which, when ionized, are converted into cations such as $\mathrm{Na}^{+}, \mathrm{K}^{+}, \mathrm{Ca}^{2+}$ and anions such as $\mathrm{Cl}^{-}, \mathrm{HCO}_{3}{ }^{-}, \mathrm{CO}^{2-}{ }_{3}$ and $\mathrm{SO}^{2-}$. These ions behave differently and are required by plants, animals, and humans in varying amounts. Therefore, it is necessary to determine the composition of effluents for cations and/or anions before their application to the soil.

According to Oteng-Peprah et al. (2018), the generation rates of domestic effluents are mostly influenced by lifestyle, types of installations used and climatic conditions. The contaminants found in greywater, for example, are largely associated with the type of detergent used and influenced by other household practices. At the same time, the treatment system interferes greatly with the final composition of the water.

On the other hand, Sandri and Rosa (2017) emphasized that the practice of reusing treated sewage effluent allows water resources with better composition to be used for more noble purposes, providing environmental, social and economic benefits, as well as reducing costs of

Rev. Ambient. Água vol. 14 n. 5, e2341 - Taubaté 2019 
agricultural production due to its great potential to provide nutrients to the plants, helping to promote sustainable agriculture and rural development. According to Monteiro et al. (2014), Lavrnié et al. (2017), Soothar et al. (2018) and Papaioannou et al. (2018), wastewater has been widely used as fertigation due to its contribution of nutrients that benefit the development of crops, its potential to improve the soil chemical properties, and because it effectively contributes to environmental protection, in addition to being a viable alternative for controlling water demand in regions with low availability of water resources. In addition, it increases crop yields and farmer profit.

Nonetheless, problems may be observed, which according to Vasudevan et al. (2010) are influenced not only by the total amount of salts present in the water but also by the types of salts, and the potential severity of the problems may vary depending on soil type, climate and crop. For irrigation purposes, TSE is highlighted for wastewater reuse, nutrient supply and the fact that it can be applied in agriculture, an activity that represents about $70 \%$ of total water consumption around the world (Almeida, 2010). According to Leuthe et al. (2019), secondary treated wastewater, a commonly used water resource in agriculture in (semi-)arid areas, often contains salts, sodium, and organic matter which may affect soil structure and hydraulic properties.

Reuse of treated domestic effluent has become a very common technique in agricultural irrigation and industrial application in many countries, such as the United States, Saudi Arabia, Egypt, Israel, Syria, Spain, Mexico, Chile and others. According to Kramer (2016), Israel stands out globally by reusing $85 \%$ of domestic sewage for irrigation after treatment, while Spain, which occupies second place in wastewater reuse, reuses only $20 \%$.

Although wastewater reuse is not a new practice and has well-proven benefits by scientific research, economic, social and environmental factors are often obstacles to wider adoption of this technology. Furthermore, the low adoption of wastewater reuse is hampered by the limitation of its integration into conventional urban treatment systems, as well as by the absence of standardization, as in the case of Brazil. This is fundamental to avoid endangering public health due to waterborne diseases and to prevent environmental damage due to its polluting potential when improperly utilized. Therefore, technical references such as that described by Ayers and Westcot (1991) have been implemented, which characterizes water used in irrigation according to the restriction potential as follows: none, mild, moderate and severe.

Numerous studies have been carried out to verify updates to crop yields and various attributes of soil irrigated with TSE, such as the electrical conductivity (EC), sodium level (Na), pH, organic matter and others (Duarte et al., 2008; Sandri et al., 2009; Oliveira et al., 2016; Urbano et al., 2015; Silva et al., 2016; Malafaia et al., 2016; Sandri and Rosa, 2017; Soothar et $a l ., 2018)$. Thus, studies indicate that one must be careful when using TSE in plant cultivation, especially with plants sensitive to saline soils. Despite this, improvement in the physical and chemical properties of the soil has been reported after the application of TSE in agriculture (Silva et al., 2014) and swine wastewater (Medeiros et al., 2011; Cabral et al., 2014), where it is affirmed that these are water sources that favor improved soil fertility.

Despite the great potential of TSE for agricultural use, if used improperly it can be harmful to the irrigation system, soil, plant, water resources and users. For example, Silva et al. (2016) found that when using treated sewage in irrigation there was a greater accumulation of micronutrients, potassium and sodium in the soil in relation to water of the public supply system, increasing the risks of sodification. Tunc and Sahin (2015) reported that soil chemical, physical and hydraulic properties can be significantly affected by irrigation with wastewater. Thus, when using TSE and groundwater for cauliflower and purple cabbage cultivation during two years in a semi-arid region with a cold climate, they observed that TSE increased the stability of aggregates, density, porosity, organic carbon and electrical conductivity of the soil, and reduced the percentage of exchangeable sodium $(<2.25 \%)$. 
Therefore, it is essential to monitor and indicate appropriate management techniques based on several aspects, including composition of the effluent and effects on the physical and chemical attributes of the soil, and when appropriate the operation of the irrigation system.

Therefore, the objective of this work was to evaluate the amount of nutrients added to RedYellow Latosol and the effect of drip irrigation with TSE on the chemical attributes of soil cultivated with bell pepper (Capsicum annuum L.), F1 Canary hybrid.

\section{MATERIAL AND METHODS}

The study was developed at the Água Limpa Farm (FAL), belonging to the University of Brasilia (UnB), located at $15^{\circ} 46^{\prime} 46^{\prime \prime} \mathrm{S}$ and $7^{\circ} 55^{\prime} 46^{\prime \prime} \mathrm{W}$, with an elevation of $1100 \mathrm{~m}$. According to the Köppen's climate classification, the region presents an Aw climate, characterized by two well-defined seasons, one hot and rainy from October to April, and another cold and dry from May to September (Álvares et al., 2013).

The average temperature from 1993 to 2013 was $22.1^{\circ} \mathrm{C}$ with average annual precipitation of 1,469 mm. The soil was classified as a typical dystrophic Red-Yellow Latosol (Embrapa, 2013), Oxisol (Typic Haplustox) (Soil Survey Staff, 1998) or Gibbsic Ferralsol (FAO, 2015). It presents a sandy texture, containing $14.2 \%$ silt, $15.0 \%$ clay and $70.8 \%$ sand, and has a soil bulk density of $1 \mathrm{~g} \mathrm{~cm}^{-3}$.

The TSE comes from the FAL/UnB refectory and toilets, characterized as essentially domestic, receiving primary treatment in three septic tanks in series, which are constructed of polyvinyl chloride (PVC) boxes with individual volume of 5,100 L. For secondary treatment, four constructed wetlands (CW) were used, arranged in parallel with dimensions of $6.5 \times 2.5 \times 0.5 \mathrm{~m}$, respectively, in length, width and height, filled with gravel \#2, which had porosity of $50 \%$, resulting in an individual useful volume of $3.82 \mathrm{~m}^{3}$. One $\mathrm{CW}$ was cultivated with taboa (Typha spp), one with Brazilian Papyrus (Cyperus Giganteus), another with white ginger lily (Hedychium coronarium Koehne), and the last was unplanted. The TSE was conducted to a vessel with a useful volume of 4,750 L and pumped to another of 2,000 L, from which it was then pumped into the irrigation system for the pepper plants.

Bell pepper (Capsicum annuum L.), F1 Canary hybrid, was cultivated from September $4^{\text {th }}$, 2015 to January $10^{\text {th }}, 2016$. The experimental design consisted of randomized blocks, with four replications for the following treatments: soil without fertilization and irrigated with river water-control (Ic); soil without fertilization and irrigated with TSE (Ie); soil with cover fertilization and irrigated with TSE (AcIe); soil with base fertilization and irrigated with river water (AbIc); soil with base fertilization and irrigated with TSE (AbIe); soil with base and cover fertilization and irrigated with TSE (AbAcIe).

Each experimental plot was planted with four rows of pepper with 5 plants each, where the plants of the two central rows were considered useful, excluding those along the border, resulting in 6 useful plants and 24 plants per treatment, with a density of 23.800 plants ha $^{-1}$. Spacing between plants in the row was $0.50 \mathrm{~m}$ and $0.80 \mathrm{~m}$ between planting rows, with each plot measuring $3.0 \mathrm{~m} \mathrm{x} 2.8 \mathrm{~m}\left(8.4 \mathrm{~m}^{2}\right)$.

Irrigation was carried out in a two-day cycle using drip tapes, arranged on the soil surface at $0.05 \mathrm{~m}$ from the plants. In-line turbulent flow emitters were used, spaced $0.30 \mathrm{~m}$ from the lateral line, with a $12 \mathrm{~mm}$ internal diameter and a flow rate of $1.3 \mathrm{~L} \mathrm{~h}^{-1}$ at a pressure of $147 \mathrm{kPa}$.

Reference evapotranspiration (ETo) was obtained by the Penman-Monteith Equation (Allen et al., 1998), estimated from climatic data provided by a meteorological station located $300 \mathrm{~m}$ from the experiment. The crop evapotranspiration $(\mathrm{Kc})$ was adjusted considering the wet area percentage of $68.5 \%$ and Kc values of 0.4 during the establishment of seedlings/vegetative, 0.7 during flowering/fruiting, 1.05 during full production and 0.85 during decline in production (Marouelli and Silva, 2012). 
During the pepper cycle adverse conditions were observed, both at low temperatures (during 46 days of the cycle the minimum temperatures were lower than $15^{\circ} \mathrm{C}$ ), as well as at temperatures above $35^{\circ} \mathrm{C}$ during 7 days of the cycle. During the flowering and full production periods, an average relative humidity of the air below the appropriate range (50 to $70 \%$ ) was recorded over the course of 62 days. Thus, these factors interfered with pepper cultivation. Although there was no etiolation, some flowers fell and there was a failure in the establishment of seedlings, reducing the development of plants and prolonging the crop cycle. The total precipitation throughout the pepper cycle was $641.55 \mathrm{~mm}$, but was more frequent as of November 2015.

TSE and river water (Ic) were analyzed at the beginning, middle and end of the experiment for the attributes presented in Table 1, according to the APHA et al. (2005) methodologies.

Before beginning the experiment, soil samples were collected at six points in the experimental area at depths of 0 to $0.2 \mathrm{~m}$. From the soil chemical analysis results, the need for liming was determined with the objective of increasing base saturation to $70 \%$. For this, $510 \mathrm{~kg} \mathrm{ha}^{-1}$ of dolomitic limestone with $100 \%$ PRNT containing $47 \% \mathrm{CaO}$ and $7 \% \mathrm{MgO}$ were applied 60 days before transplanting (DAT).

Table 1. Physical-chemical attributes of the treated sewage effluent (Ie) and river water (Ic) used in irrigation of the yellow pepper crop.

\begin{tabular}{|c|c|c|c|}
\hline Attributes & Unit & Ic & $\mathrm{Ie}$ \\
\hline Hydrogen Potential (pH) & Units & 8.30 & 7.05 \\
\hline Electrical Conductivity (EC) & $\mathrm{dS} \mathrm{m}^{-1}$ & 0.003 & 0.530 \\
\hline Temperature & ${ }^{\circ} \mathrm{C}$ & 26.10 & 26.70 \\
\hline Suspended Solids (SS) & $\mathrm{mg} \mathrm{L}^{-1}$ & 0.00 & 68.50 \\
\hline Total Dissolved Solids (TDS) & $\mathrm{mg} \mathrm{L} \mathrm{L}^{-1}$ & 1.92 & 339.2 \\
\hline Turbidity & NTU & 4.88 & 29.005 \\
\hline Nitrite $\left(\mathrm{N}-\mathrm{NO}^{-}\right)^{2}$ & $\mathrm{mg} \mathrm{L}{ }^{-1}$ & 0.002 & 0.034 \\
\hline Ammonia $\left(\mathrm{N}-\mathrm{NH}_{3}\right)$ & $\mathrm{mg} \mathrm{L}^{-1}$ & 0.035 & 3.695 \\
\hline Nitrate $\left(\mathrm{NO}^{-}\right)^{3}$ & $\mathrm{mg} \mathrm{L} \mathrm{L}^{-1}$ & 0.33 & 1.79 \\
\hline Total Nitrogen ( $\mathrm{N}$ total) & $\mathrm{mg} \mathrm{L}^{-1}$ & 7.00 & 37.80 \\
\hline Potassium (K) & $\mathrm{mg} \mathrm{L}^{-1}$ & 0.00 & 38.87 \\
\hline $\operatorname{Iron}(\mathrm{Fe})$ & $\mathrm{mg} \mathrm{L}{ }^{-1}$ & 0.26 & 0.26 \\
\hline Total Phosphate (P) & $\mathrm{mg} \mathrm{L}^{-1}$ & 1.10 & 1.80 \\
\hline Manganese (Mn) & $\mathrm{mg} \mathrm{L}^{-1}$ & 0.05 & 0.05 \\
\hline Boron (B) & $\mathrm{mg} \mathrm{L}^{-1}$ & 0.31 & 0.49 \\
\hline Sulfur (S) & $\mathrm{mg} \mathrm{L} \mathrm{L}^{-1}$ & 1.00 & 1.00 \\
\hline Sodium (Na) & $\mathrm{mg} \mathrm{L}{ }^{-1}$ & 0.06 & 2.97 \\
\hline Calcium (Ca) & $\mathrm{mg} \mathrm{L}^{-1}$ & 0.68 & 0.98 \\
\hline Magnesium (Mg) & $\mathrm{mg} \mathrm{L}^{-1}$ & 0.11 & 0.12 \\
\hline $\mathrm{SAR}^{1}$ & $\left(\mathrm{mmol}_{\mathrm{c}} \mathrm{L}^{-1}\right)^{0.5}$ & 0.10 & 4.01 \\
\hline
\end{tabular}


After liming, new soil sampling was performed at depths of 0.0 to $0.2 \mathrm{~m}$ and the results of the chemical analysis (Table 2) were used to calculate the base and cover fertilization needs. In base fertilization, $80 \mathrm{~kg}$ of $\mathrm{P}_{2} \mathrm{O}_{5}$ and $50 \mathrm{~kg}$ of $\mathrm{K}_{2} \mathrm{O} \mathrm{ha}^{-1}$ were applied, in the form of simple superphosphate and potassium chloride, respectively. These fertilizers were applied throughout the area and incorporated into the soil.

Table 2. Values of soil chemical attributes in the 0 to $0.2 \mathrm{~m}$ layer at the beginning of the experiment with pepper cultivation.

\begin{tabular}{lccccccccccc}
\hline $\mathrm{pH}$ & $\mathrm{OM}$ & $\mathrm{K}^{+}$ & $\mathrm{Ca}^{2}+$ & $\mathrm{Mg}^{2+}$ & $\mathrm{Al}^{3+}$ & $\mathrm{H}^{+} \mathrm{Al}$ & $\mathrm{CECe}$ & $\mathrm{CECt}$ & $\begin{array}{c}\mathrm{P} \\
\mathrm{cmol}_{\mathrm{c}} \mathrm{dm}^{-3}\end{array}$ & $\begin{array}{c}\mathrm{m} \\
\mathrm{H}_{2} \mathrm{O}\end{array}$ & $\mathrm{g} \mathrm{kg}^{-1}$ \\
5.9 & 11.25 & 0.12 & 5.18 & 3.25 & 0.15 & 7.7 & 8.68 & 16.23 & 0.88 & 0.95 & 52.3 \\
\hline
\end{tabular}

pH: pH in water; OM: Organic matter; K: Extractable Potassium; Ca: Extractable Calcium; Mg: Extractable Magnesium; $\mathrm{Al}^{3+}$ : Exchangeable Aluminum; $\mathrm{H}+\mathrm{Al}$ : Potential Acidity; CECe: Effective cation exchange capacity; CECt: total cation exchange capacity; m: Aluminum saturation; V: Base Saturation and P: Extractable Phosphorus.

As cover fertilizer, $165 \mathrm{~kg} \mathrm{ha}^{-1}$ of $\mathrm{N}$ and $180 \mathrm{~kg} \mathrm{ha}^{-1}$ of $\mathrm{K}_{2} \mathrm{O}$ in the form of urea and potassium chloride were applied, respectively. These amounts were divided into 7 applications throughout the crop cycle. The first application took place at planting, the second 20 days after transplanting and the others at every 15 days. In addition, $300 \mathrm{~kg} \mathrm{ha}^{-1}$ of $\mathrm{P}_{2} \mathrm{O}_{5}$, in the form of single superphosphate, were applied in a single application 10 days before transplanting. All applications followed the recommendation of Ribeiro et al. (1999).

At the end of the experiment, 24 soil samples were collected, one from each plot, in the 0 to $0.2 \mathrm{~m}$ layer and located in the center of the wet bulb formed by the dripper. Three sub samples were collected in the plot to make up the sample.

The samples were homogenized, air-dried and passed through a $2 \mathrm{~mm}$ mesh sieve to perform soil chemical analyses. The soil chemical properties were determined according to Silva (1999). In brief, the $\mathrm{pH}$ was determined in $\mathrm{H}_{2} \mathrm{O}$ using a 1:2.5 (w/v) soil: solution ratio suspension; $0.5 \mathrm{~mol} \mathrm{~L}^{-1}$ potassium chloride was used as an extractor in the determination of the calcium $\left(\mathrm{Ca}^{2+}\right)$, magnesium $\left(\mathrm{Mg}^{2+}\right)$ and exchangeable aluminum $\left(\mathrm{Al}^{3+}\right)$ contents. This solution was left for overnight equilibration. Subsequently, $\mathrm{Ca}^{2+}$ and $\mathrm{Mg}^{2+}$ were determined by atomic absorption spectrometry (Shimadzu AA-6300) and $\mathrm{Al}^{3+}$ by titration with a $0.01 \mathrm{~mol} \mathrm{~L}^{-1}$ sodium hydroxide solution. The potassium and phosphorus contents were determined using the Mehlich-1 extractor and analyzed by flame spectrophotometry $\left(\mathrm{K}^{+}\right)$. Aluminum saturation was calculated as follows: $\mathrm{m}, \%=\left(\mathrm{Ca}^{2+}+\mathrm{Mg}^{2+}+\mathrm{K}^{+}\right) / \mathrm{Al}^{3+}$.

Data were submitted to analysis of variance (one-way ANOVA) followed by the Duncan test $(\mathrm{P}<0.05)$ as a post-hoc to detect statistical significant differences among all treatments. Normality and homoscedasticity of the residues were evaluated by the Lilliefors and Cochran's C tests, respectively. The XLSTAT 2015 software was used for statistical analyses (Addinsoft, 2016).

\section{RESULTS AND DISCUSSION}

\subsection{Attributes of the river water and treated sewage effluent}

In irrigation with the treated sewage effluent (Ie), the $\mathrm{pH}$ and magnesium were generally lower than in river water (Ic), while electrical conductivity, suspended and total solids, turbidity, nitrite, ammonia, nitrate, sodium, potassium, total nitrogen and total phosphate were higher than in river water (Ic) (Table 1).

Ic showed no restriction of irrigation use in relation to boron, EC, sodium and SAR; however, total nitrogen and magnesium showed a slight or moderate restriction according to 
Ayers and Westcot (1991) classification. On the other hand, Almeida (2010) reported that all attributes evaluated in the Ic are within a normal range for irrigation application. The EC value obtained in the effluent of $0.53 \mathrm{dS} \mathrm{m}^{-1}$ has no restriction for use in irrigation (Ayers and Westcot, 1991), possibly due to low solids loading in the sewage because it is mainly from the refectory. The content of diluted salts decreased in the effluent, due to the lower availability of organic matter for mineralization. This value is lower than that obtained by Urbano et al. (2015) of $0.83 \mathrm{dS} \mathrm{m}^{-1}$ and Sandri and Rosa (2017) of $2.01 \mathrm{dS} \mathrm{m}^{-1}$, whereas Oliveira et al. (2016) observed $\mathrm{EC}$ of $1.55 \mathrm{dS} \mathrm{m}^{-1}$, where in these cases the restriction is slight or moderate.

The level of total $\mathrm{Fe}$ was $0.26 \mathrm{mg} \mathrm{L}^{-1}$ in both the river and Ie water, in agreement with Metcalf and Eddy (1991) who recommend irrigation values up to $5.0 \mathrm{mg} \mathrm{L}^{-1}$, because higher values begin to present toxicity problems for crops. According to these authors, this value is not toxic to soils with good aeration, although it contributes to make phosphorus and molybdenum unavailable to plants. The level of iron obtained in Ie was lower than that observed by Sandri et al. (2009), who verified a maximum value of $1.8 \mathrm{mg} \mathrm{L}^{-1}$ in effluent from a university unit, treated with septic tanks followed by constructed wetlands filled with gravel \#2 and cultivated with macrophyte Typha sp ("taboa").

Likewise, Ie did not present restrictions regarding the levels of $\mathrm{B}, \mathrm{pH}, \mathrm{Mg}, \mathrm{NO}_{3}, \mathrm{EC}$ and RAS according to Almeida (2010); but according to Ayers and Westcot (1991), when EC and RAS are analyzed together, they express a slight or moderate restriction. The same occurred for

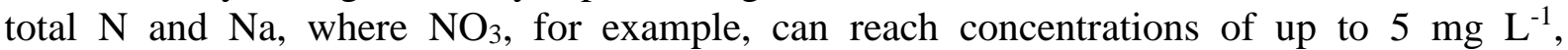
significantly higher than that observed in Ie which was $0.034 \mathrm{mg} \mathrm{L}^{-1}$. In turn, the average levels of $\mathrm{Mg}$ were $0.05 \mathrm{mg} \mathrm{L}^{-1}$ for Ic and Ie (Table 1), also lower than those recommended by Metcalf and Eddy (1991) for irrigation water. When the wastewater has a high concentration of nitrogen, this nutrient can be retained in the soil at the time of reuse. This was demonstrated in a study carried out by Sun et al. (2018), that when evaluating the $\mathrm{NO}_{3}{ }^{-}$removal efficiencies in soil column under laboratory conditions filled with sterilized soil (SS), silty clay (SC), soil with submerged plant (SSP) and soil mixed with biochar (BCS) for constant concentration of $\mathrm{NO}_{3}^{-}$ of $15 \mathrm{mg} \mathrm{L}^{-1}$ and flow rate of $0.6 \pm 0.1 \mathrm{~m} \mathrm{~d}^{-1}$, concluded that both SSP and BCS were able to provide levels of $\mathrm{NO}_{3}{ }^{-}<0.2 \mathrm{mg} \mathrm{L}^{-1}$ in the wastewater percolated in the column.

The values of $\mathrm{Na}$ and $\mathrm{Ca}$ were considered high, which is justified by the fact that the sewages were composed predominantly of food and cleaning product residues produced in the refectory, reaching $2.97 \mathrm{mmol}_{\mathrm{c}} \mathrm{L}^{-1}$ and $0.98 \mathrm{mmol}_{\mathrm{c}} \mathrm{L}^{-1}$, respectively, lower than those obtained by Oliveira et al. (2016) for domestic sewage. As a consequence, the obtained SAR value was $4.01\left(\mathrm{mmol}_{\mathrm{c}} \mathrm{L}^{-1}\right)^{0.5}$, lower than those obtained by the authors above, who observed a value of $7.8\left(\mathrm{mmol}_{\mathrm{c}} \mathrm{L}^{-1}\right)^{0.5}$, but higher than that of Sandri and Rosa (2017) with $0.87\left(\mathrm{mmol}_{\mathrm{c}} \mathrm{L}^{-1}\right)^{0.5}$. The SAR obtained in this work is considered of slight or moderate restriction for irrigation use. However, because the irrigation time was short and the soil presented a high infiltration velocity $\left(192 \mathrm{~mm} \mathrm{~h}^{-1}\right)$, no significant accumulation of these attributes in the soil was observed.

\subsection{Chemical attributes of the soil}

Regarding the chemical attributes present in the soil at the end of the experiment, it is observed that only the $\mathrm{K}^{+}$content was affected by the different treatments $(\mathrm{P}<0.05)$, where the AbAcIe treatment resulted in a higher value when compared to the treatments Ie and AcIe (Table 3). In the soil layer evaluated from 0 to $0.20 \mathrm{~m}$, the highest values were $0.12 \mathrm{cmol}_{\mathrm{c}} \mathrm{dm}^{3}$ and $0.09 \mathrm{cmol}_{\mathrm{c}} \mathrm{dm}^{-3}$, respectively, for the treatments AbAcIe and Ie, while Oliveira et al. (2016) observed a value of 0.3 to $0.4 \mathrm{cmol}_{\mathrm{c}} \mathrm{dm}^{-3}$. Sandri and Rosa (2017) also observed variation with the use of well water between the micro sprinkler and drip irrigation and between the beginning and the end of the experiment in the layer from 0 to $0.20 \mathrm{~m}$. According to these authors, in the soil layer of 0.2 to 0.4 , except for the well water treatment applied by a micro sprinkler, every other treatment using well water and treated effluent presented significant elevations. 
This behavior, according to Doblinski et al. (2010), is attributed to the mobility of $\mathrm{K}^{+}$in the soil profile, which is much greater than that of phosphorus. It is favored by irrigation water, but also by natural precipitation during the experiment. This also reinforces the authors' report that when applying swine wastewater in the bean crop greater mobility in the soil profile is found for potassium, followed by nitrogen and phosphorus.

Considering the irrigation application of $253.1 \mathrm{~mm}$ during the crop cycle, $9.57 \mathrm{~kg} \mathrm{ha}^{-1}$ of total $\mathrm{N}$ (composed of approximately $10 \%$ of ammonia, $5 \%$ of nitrate, $1 \%$ of nitrite and $84 \%$ of organic $\mathrm{N}), 9.84 \mathrm{~kg} \mathrm{ha}^{-1}$ of total potassium $\left(11.85 \mathrm{~kg} \mathrm{ha}^{-1}\right.$ of $\left.\mathrm{K}_{2} \mathrm{O}\right)$ and $0.46 \mathrm{~kg} \mathrm{ha}^{-1}$ of total phosphate $\left(1.04 \mathrm{~kg} \mathrm{ha}^{-1}\right.$ of $\left.\mathrm{P}_{2} \mathrm{O}_{5}\right)$ were applied. While for Ic, the increase in total $\mathrm{N}$ was only $1.77 \mathrm{~kg} \mathrm{ha}^{-1}$ and $0.28 \mathrm{~kg} \mathrm{ha}^{-1}$ of total phosphate, with no increase in total potassium.

Table 3. Chemical attributes of the soil evaluated at the end of the pepper experiment for different treatments in the soil layer from 0 to $0.2 \mathrm{~m}$.

\begin{tabular}{lccccc}
\hline \multicolumn{5}{c}{ Soil Attributes } \\
\hline Treatments & $\begin{array}{c}\mathrm{Al}^{3+} \\
\left(\mathrm{cmol}_{\mathrm{c}} \mathrm{dm}^{-3}\right)\end{array}$ & $\begin{array}{c}\mathrm{H}+\mathrm{Al} \\
\left(\mathrm{cmol}_{\mathrm{c}} \mathrm{dm}^{-3}\right)\end{array}$ & $\mathrm{CEC}$ & $\begin{array}{c}\mathrm{V} \\
(\%)\end{array}$ & $\begin{array}{c}\mathrm{TOM} \\
\left(\mathrm{g} \mathrm{kg}^{-1}\right)\end{array}$ \\
\hline AbAcIe & $0.018 \mathrm{a}$ & $3.3 \mathrm{a}$ & $7.3 \mathrm{a}$ & $54.8 \mathrm{a}$ & $61.4 \mathrm{a}$ \\
$\mathrm{Ie}$ & $0.010 \mathrm{a}$ & $3.1 \mathrm{a}$ & $7.4 \mathrm{a}$ & $58.4 \mathrm{a}$ & $57.4 \mathrm{a}$ \\
$\mathrm{Ic}$ & $0.015 \mathrm{a}$ & $2.9 \mathrm{a}$ & $7.4 \mathrm{a}$ & $60.5 \mathrm{a}$ & $58.8 \mathrm{a}$ \\
AcIe & $0.013 \mathrm{a}$ & $3.0 \mathrm{a}$ & $7.4 \mathrm{a}$ & $59.3 \mathrm{a}$ & $50.8 \mathrm{a}$ \\
AbIc & $0.015 \mathrm{a}$ & $3.0 \mathrm{a}$ & $7.1 \mathrm{a}$ & $57.4 \mathrm{a}$ & $53.9 \mathrm{a}$ \\
AbIe & $0.013 \mathrm{a}$ & $3.2 \mathrm{a}$ & $7.2 \mathrm{a}$ & $53.8 \mathrm{a}$ & $57.7 \mathrm{a}$ \\
\hline & & $\mathrm{P}$ & $\mathrm{K}^{+}$ & $\mathrm{Ca}^{2+}$ & $\mathrm{Mg}^{2+}$ \\
Treatments & $\mathrm{pH}\left(\mathrm{CaCl}_{2}\right)$ & $\left(\mathrm{mg} \mathrm{dm}^{-3}\right)$ & $\left(\mathrm{cmol}_{\mathrm{c}} \mathrm{dm}^{-3}\right)$ & $\left(\mathrm{cmol}_{\mathrm{c}} \mathrm{dm}^{-3}\right)$ & $\left(\mathrm{cmol}_{\mathrm{c}} \mathrm{dm}^{-3}\right)$ \\
\hline AbAcIe & $5.9 \mathrm{a}$ & $6.1 \mathrm{a}$ & $0.120 \mathrm{a}$ & $3.0 \mathrm{a}$ & $0.9 \mathrm{a}$ \\
Ie & $6.0 \mathrm{a}$ & $5.4 \mathrm{a}$ & $0.09 \mathrm{ab}$ & $3.2 \mathrm{a}$ & $1.0 \mathrm{a}$ \\
Ic & $6.0 \mathrm{a}$ & $5.4 \mathrm{a}$ & $0.07 \mathrm{~b}$ & $3.3 \mathrm{a}$ & $1.0 \mathrm{a}$ \\
AcIe & $6.0 \mathrm{a}$ & $6.0 \mathrm{a}$ & $0.08 \mathrm{~b}$ & $3.4 \mathrm{a}$ & $0.9 \mathrm{a}$ \\
AbIc & $6.0 \mathrm{a}$ & $4.4 \mathrm{a}$ & $0.09 \mathrm{ab}$ & $3.0 \mathrm{a}$ & $1.0 \mathrm{a}$ \\
AbIe & $5.9 \mathrm{a}$ & $5.7 \mathrm{a}$ & $0.09 \mathrm{ab}$ & $2.9 \mathrm{a}$ & $0.9 \mathrm{a}$ \\
\hline
\end{tabular}

Soil without fertilization and irrigated with river water (Ic), soil without fertilization and irrigated with TSE (Ie), soil with cover fertilization and irrigated with TSE (AcIe), soil with base fertilization and irrigated with river water (AbIc), soil with base fertilization and irrigated with TSE (AbIe), soil with base and cover fertilization and irrigated with TSE (AbAcIe). Total organic matter (TOM), base saturation (V)

Although the salt concentrations of practically all attributes evaluated in the effluent (Ie) were higher than in the river water (Ic), no toxicity symptoms were verified in the plants and no changes in the chemical properties in the soil that could compromise the development of the plants were found. Contrarily, there was an increase in salts in the soil, although not significant, except for $\mathrm{K}^{+}$, which is beneficial for the plants. Cunha et al. (2014) reported that the amounts of nitrogen, phosphorus and potassium in treated sewage effluent represent savings in the acquisition of synthetic nutrient salts, which improves the cost-benefit ratio compared to irrigation with natural water. These authors obtained savings ranging from 65 to $100 \%$ of calcium, sulfate, copper and molybdenum.

When comparing the quantities of nutrients in the effluent with the amounts in synthetic formulations to meet crop demand, the values are generally very small, since the quantities demanded by plants are high, especially macronutrients. At the same time, effects of using the effluent on chemical attributes of the soil are very variable among works published in literature (Sandri et al., 2009; Andrade Filho et al., 2013; Oliveira et al., 2016; Silva et al., 2016; Malafaia 
et al., 2016; Sandri and Rosa, 2017), influenced by several factors, such as irrigation system, soil water distribution, $\mathrm{pH}$ and soil organic matter. As demonstrated by Kalavrouziotis et al. (2018), both $\mathrm{pH}$ and organic matter were significantly related to the level of immobilization and adsorption of heavy metals in the soil. Rahav et al. (2017) evaluated the spatial and temporal distribution of water content and chemical properties of the soil in the root zone after application of $700 \mathrm{~mm}$ of TSE and natural water by surface drip. These authors verified the existence of preferential flow, which led to the uneven distribution of soil chemical properties, with substantially high concentrations at the driest and lowest points in the wet points.

Rahav et al. (2017), after application of TSE with high concentrations of salts and nutrients, verified high salinity, SAR and nutrient concentrations in the root zone of citrus plants. Silva et al. (2016), for example, found that irrigation with treated sewage provides a greater accumulation of micronutrients, potassium and sodium in the soil, increasing the risks of sodification in irrigated areas when compared to water from the public supply system, when testing five doses of nitrogenous fertilization $\left(0,45,90,135\right.$ and $\left.180 \mathrm{~kg} \mathrm{ha}^{-1}\right)$. In turn, Urbano et al. (2015) concluded that the reuse of domestic effluents did not cause damage to the physical properties of the soil, but resulted in a tendency for salinization when irrigation was performed in undisturbed soil samples arranged in a constant load permeameter to simulate irrigation equivalent to 5 cycles of lettuce cultivation. Barreto et al. (2013), similar to other authors, verified that after the application of wastewater to soil the levels of phosphorus, calcium, potassium and organic matter, mainly in the superficial layer (0 to $10 \mathrm{~cm})$, and sodium, at depth (up to $50 \mathrm{~cm}$ ), increased significantly compared with the application of water from public supply. In turn, Andrade Filho et al. (2013), when applying different doses of the domestic effluent in Cambisol, observed that the attributes $\mathrm{pH}, \mathrm{MO}, \mathrm{P}, \mathrm{K}^{+}, \mathrm{Na}^{+}, \mathrm{Mg}^{2+}, \mathrm{Al}^{3+}$ and $\mathrm{H}+\mathrm{Al}$ were significantly altered.

Different from the results obtained in this experiment, in the study performed by Duarte et al. (2008) the use of TSE in a soil cultivated with pepper promoted an increase only in the levels of organic matter of the soil when compared with the application of well water. On the other hand, Sandri et al. (2009) reported that after two cultivation cycles of Elisa lettuce, TSE irrigation promoted higher levels of potassium, manganese, copper, sulfur and electrical conductivity, but there was no observed difference in CEC, organic matter, magnesium, calcium, total nitrogen, sodium and phosphorus when compared to dam water. Sandri and Rosa (2017), when irrigating banana trees with surface drip irrigation and micro sprinkler using treated sewage effluent (Ie), conventional fertigation and well water, observed that the levels of $\mathrm{Na}$ and $\mathrm{B}$ declined or remained stable in the soil, but drip application of the effluent raises the levels of phosphorus, sulfur, total acidity and base saturation in the soil layer from 0 to $0.2 \mathrm{~m}$ and when using the micro sprinkler in the layer of 0.2 to $0.4 \mathrm{~m}$.

Soothar et al. (2018) concluded that the use of untreated sewage had unacceptable levels of $\mathrm{EC}, \mathrm{pH}, \mathrm{K}^{+}, \mathrm{Na}^{+}$and $\mathrm{Cl}^{-}$, which resulted in excessive concentrations of these ions in both rice plant (Oryza sativa) and irrigated soil. In view of the conclusion of these authors, it is verified that the type of sewage treatment can be a differential, thus, the use of SZR can be an alternative in the sense of assisting in the previous removal of part of the fertilizers present in the effluent.

Phosphorus is commonly present at high concentrations in TSE due to its presence in soaps that are easily conducted by water. Therefore, it is common to find significant differences in its concentration when compared to natural water. This did not occur in the present study, possibly because soap was not used to clean the facilities of the refectory. Cabral et al. (2014), when applying the doses of $0,150,300,450,600$ and $750 \mathrm{~m}^{3} \mathrm{ha}^{-1}$ of swine wastewater to an area of elephant grass cultivation, concluded that in the first stage there was an increase but in the second stage there was a reduction of $\mathrm{P}$ in the soil, and the same occurred for $\mathrm{K}^{+}$and $\mathrm{Ca}^{2+}$.

Musazura et al. (2019), when using TSE and natural water in banana and taro irrigation, 
did not find significant differences in $\mathrm{N}$ and $\mathrm{P}$ uptake by the two crops; however, irrigation with treated effluent increased significantly inorganic $\mathrm{N}$ and $\mathrm{P}$, especially at the depth of $0.3 \mathrm{~m}$ of the soil. The authors also concluded that there was no difference between the types of irrigation related to phosphorus leaching, but obtained a higher concentration of inorganic $\mathrm{N}$ in TSE leachates up to $0.3 \mathrm{~m}$ of soil depth.

Other attributes, such as organic matter and nitrogen, also showed differences in this type of experiment; however the differences are dependent on concentrations in the TSE, the application period and the respective climatic and soil conditions. Garcia et al. (2012), cultivating fertirrigated forages with TSE confirmed increases in the levels of phosphorus, potassium and base saturation, a fact that in the present study only occurred with potassium.

In general, the average levels of magnesium in Ie were below those considered adequate. However, in Ic they were slightly higher than those in Ie (Table 1), but not enough to generate a statistical difference in the soil between treatments (Table 3), and with no indication of leaching. This was also observed by Medeiros et al. (2011) when analyzing the soil profile to a depth of $1.0 \mathrm{~m}$ with collections every $0.2 \mathrm{~m}$ for different dosages of swine effluent. Although aluminum was not evaluated in the irrigation water, in the soil this element was not affected by the different treatments applied.

Although Ie presented a higher concentration of calcium than Ic (Table 1), the soil that received this effluent showed no change in relation to the beginning of the experiment (Table 3). This may have occurred due to high consumption by the plant which may not have reached its maximum potential in treatments without Ie due to possible deficiencies of other nutrients, causing the plant to not require high calcium absorption. Another possible factor is the fact that the increase in sodium from Ie displaced calcium, making it more susceptible to leaching. Despite the huge increase in TOM levels, there was no statistical difference between the treatments, with levels varying from 9 to $14 \mathrm{~g} \mathrm{~kg}^{-1}$ and an average value of $11.25 \mathrm{~g} \mathrm{~kg}^{-1}$ before beginning the experiment. At the end of the experiment, the TOM varied from 50.9 to $61.4 \mathrm{~g} \mathrm{~kg}^{-1}$ between treatments. The fact that Ie did not cause the accumulation of TOM in the soil may be due to the rapid mineralization of this attribute, promoted by the environment considered favorable for microbial activity in the soil (Table 3).

These results reinforce the conclusions of Duarte et al. (2008), who in a study evaluating the application of TSE in the soil observed lower concentrations of TOM in these treatments compared to natural water, justified as a result of the easy decomposition of the organic matter existing in the effluent. Another factor is that the TOM levels in the TSE were not that high when compared to Ic, possibly due to the fact that the sewage is mostly generated by the refectory (low concentration of solids). Finally, removal of organic matter is remarkably efficient in the cultivated wetlands sewage treatment system, and also because the effluent is filtered through a 125 micron disk filter before being applied via drip irrigation.

The absence of significant increases in soil nutrients in this experiment, commonly cited in other works, may be associated with the short application period and the rainy period occurring at the end of the cycle. At the same time, there may have been leaching of salts in the soil profile, since the local soil presents a high rate of basic infiltration (RBI), which on average is $192 \mathrm{~mm} \mathrm{~h}^{-1}$.

Therefore, additional studies should be carried out with a larger number of crop cycles aiming to extend the period of application, considering the climatic conditions of the site, soil types, sewage treatment system and irrigation system.

\subsection{Plant height, fresh mass of fruits and productivity of the bell pepper}

There was no difference in the plant height between the treatments, a behavior also verified by Sousa et al. (2006) when irrigating the bell pepper with the effluent from an anaerobic decomposition reactor and well water. In addition, in the present study the plant height was 
lower than that indicated by the company which developed the F1 Canary pepper $(120 \mathrm{~cm})$, ranging from $30 \%$ (Ie) to $38.3 \%$ (AcIe) of the expected height. This can be explained by the absence of competition for luminosity, thus allowing greater horizontal growth than vertical growth.

The application of TSE, exclusively or combined with mineral fertilization, promoted higher pepper productivity than the use of river water, reaching $5.85 \mathrm{t} \mathrm{ha}^{-1}$ in Ie (Table 4). Furthermore, in the treatments irrigated with TSE (AbAcIe, Ie, AcIe and AbIe), the yields obtained were higher than those predicted by the company which developed the cultivar. However, when irrigation was performed with river water (Ic and AbIc), the yield was lower than expected.

Table 4. Plant height, fresh mass of fruits and productivity of the bell pepper, F1 Canary hybrid, at 140 DAT and variation, in percentage, in relation to that expected for the cultivar according to the company which developed the hybrid.

\begin{tabular}{lccccc}
\hline Treatment & PH $(\mathrm{cm})$ & PH $(\%$ of expected $)$ & FMV $\left(\mathrm{g} \mathrm{fruit}^{-1}\right)$ & ${\text { Prod. }\left(\mathrm{t} \mathrm{ha}^{-1}\right)}$ & $\begin{array}{c}\text { Prod. } \\
(\% \text { of expected })\end{array}$ \\
\hline AbAcIe & 43 & 35.8 & $230.1 \mathrm{a}$ & $5.67 \mathrm{a}$ & 115.7 \\
Ie & 36 & 30.0 & $195.9 \mathrm{ab}$ & $5.85 \mathrm{a}$ & 119.3 \\
Ic & 42 & 35.0 & $160.0 \mathrm{~b}$ & $4.44 \mathrm{~b}$ & 90.6 \\
AcIe & 46 & 38.3 & $187.9 \mathrm{ab}$ & $5.62 \mathrm{a}$ & 114.7 \\
AbIc & 43 & 35.8 & $165.7 \mathrm{~b}$ & $4.16 \mathrm{~b}$ & 84.9 \\
AbIe & 39 & 32.5 & $202.7 \mathrm{ab}$ & $5.76 \mathrm{a}$ & 117.6 \\
\hline
\end{tabular}

Soil with base and cover fertilization and irrigated with TSE (AbAcIe), soil without fertilization and irrigated with TSE (Ie), soil without fertilization and irrigated with river water (Ic), soil with cover fertilization and irrigated with TSE (AcIe), soil with base fertilization and irrigated with river water (AbIc), soil with base fertilization and irrigated with TSE (AbIe). Plant height (PH), Fresh mass of the fruits (FMV) and productivity (Prod.).

The fresh mass of the fruits in AbAcIe (230.1 $\mathrm{g}_{\text {fruit }}{ }^{-1}$ ) was higher than in the treatments that used river water (Ic - $160.0 \mathrm{~g}$ fruit $^{-1}$ and AbIc - $165.7 \mathrm{~g}$ fruit $^{-1}$ ), and similar to those which used TSE. This shows that the TSE provides better conditions for the growth of the bell peppers, corroborating the results obtained by Sousa et al. (2006).

\section{CONCLUSIONS}

During the pepper crop cycle, $10 \mathrm{~kg} \mathrm{ha}^{-1}$ of total nitrogen, $10 \mathrm{~kg} \mathrm{ha}^{-1}$ of total potassium and $0.5 \mathrm{~kg} \mathrm{ha}^{-1}$ of total phosphate were added to the soil by means of irrigation with TSE. Irrigation performed exclusively with the effluent (Ie) in the pepper crop increased the levels of potassium, but did not affect phosphorus, organic matter and soil $\mathrm{pH}$ at the end of the growing cycle. In general, TSE application, exclusive or combined with mineral fertilization, promoted higher pepper productivity than the use of river water, even when it was supplemented with mineral fertilizer. TSE irrigation combined with mineral fertilization (base and cover) also promoted a higher mass of pepper fruits in relation to irrigation with river water. However, in order to identify changes in soil chemical attributes due to the application of domestic sewage effluent, additional studies should be carried out with a larger number of crop cycles aiming to extend the period of application, considering the climatic conditions of the site, soil types, sewage treatment system and irrigation system.

\section{ACKNOWLEDGMENTS}

To CNPq for the financial assistance. Universal Call - MCTI/CNPq No 14/2013. Process: 480332/2013-4. 


\section{REFERENCES}

ADDINSOFT. XLSTAT statistical analysis software: version 2015. 2016. Available at: www.xlstat.com. Access: 12 Dec. 2015.

ALMEIDA, O. A. Qualidade da água de irrigação. Cruz das Almas: Embrapa Mandioca e Fruticultura, 2010. 228 p.

ÁLVARES, C. A.; STAPE, J. L.; SENTELHAS, P. C.; GONÇALVES, J. L. M.; SPAROVEK, G. Köppen's climate classification map for Brazil. Meteorologische Zeitschrift, v. 22, n. 6, p. 711-728, 2013. https://doi.org/10.1127/0941-2948/2013/0507

ALLEN, R. G.; PEREIRA, L. S.; RAES, D.; SMITH, M. Crop evapotranspiration: guidelines for computing crop water requirements. Rome: FAO, 1998. 297p.

ANDRADE FILHO, J. A.; SOUSA NETO, O. N.; DIAS, N. S.; NASCIMENTO, L. B.; MEDEIROS, J. F.; COSME, C. R. Atributos químicos de solo fertirrigado com água residuária no semiárido brasileiro. Irriga, v. 18, n. 4, p. 661-674, 2013. https://doi.org/10.15809/irriga.2013v18n4p661

APHA; AWWA; WEF. Standard methods for examination of water and wastewater. $21^{\text {st }}$. ed. Washington, DC, 2005.

AYERS, R. S.; WESTCOTT, D. W. A qualidade da água na agricultura. Campina Grande: UFPB, 1991. $218 \mathrm{p}$.

BARRETO, A. N.; NASCIMENTO, J. J. V. R.; MEDEIROS, E. P.; NÓBREGA, J. A.; BEZERRA, J. R. C. Changes in chemical attributes of a Fluvent cultivated with castor bean and irrigated with wastewater. Revista Brasileira de Engenharia Agrícola e Ambiental, v. 17, n. 5, p. 480-486, 2013. http://dx.doi.org/10.1590/S141543662013000500003

BEDBABIS, S.; ROUINA, B. B.; BOUKHRIS, M.; FERRARA, G. Effect of irrigation with treated wastewater on soil chemical properties and infiltration rate. Journal of $\begin{array}{llllll}\text { Environmental Management, v. 133, p. 45-50, } 2014 . & \end{array}$ https://dx.doi.org/10.1016/j.jenvman.2013.11.007

CABRAL, J. R.; FREITAS, P. S. L.; REZENDE, R.; MUNIZ, A. S.; BERTONHA, A. Changes in chemical properties of dystrophic Red Latosol as result of swine wastewater application. Revista Brasileira de Engenharia Agrícola e Ambiental, v. 18, n. 2, p. 210-216, 2014. http://dx.doi.org/10.1590/S1415-43662014000200012

CUNHA, A. H. N.; SANDRI, S.; VIEIRA, J. A.; CORTEZ, T. B.; OLIVEIRA, T. H. Sweet grape mini tomatoes grown in culture substrates and effluent with nutrient complementation. Engenharia Agrícola, v. 34, n. 4, p. 707-715, 2014. http://dx.doi.org/10.1590/S0100-69162014000400010

DOBLINSKI, A. F.; SAMPAIO, S. C.; SILVA, V. R. D A.; NÓBREGA, L. H. P.; GOMES, S. D.; DAL BOSCO, T. C. Nonpoint source pollution by swine farming wastewater in bean crop. Revista Brasileira de Engenharia Agrícola e Ambiental, v. 14, n. 1, p. 87-93, 2010. http://dx.doi.org/10.1590/S1415- 43662010000100012

DUARTE, A. S; AIROLDI, R. P. S.; FOLEGATTI, M. V.; BOTREL, T. A.; SOARES, T. M. Efeitos da aplicação de efluente tratado no solo: $\mathrm{pH}$, matéria orgânica, fósforo e potássio. Revista Brasileira de Engenharia Agrícola e Ambiental, Campina grande, v. 12, n. 3, p. 302-310, 2008. https://dx.doi.org/10.1590/S1415-43662008000300012 
EMBRAPA. Centro Nacional de Pesquisas de Solos. Sistema brasileiro de classificação de solos. 3. ed. Rio de Janeiro, 2013. 353p.

FAO. World reference base for soil resources 2014: international soil classification system for naming soils and creating legends for soil maps update 2015. Rome, 2015. $192 \mathrm{p}$.

GARCIA, G. O.; RIGO, M. M.; CECÍLIO, R. A.; REIS, E. F.; BAUER, M. O.; RANGEL, O. J. P. Propriedades químicas de um solo cultivado com duas forrageiras fertirrigadas com esgoto doméstico tratado. Revista Brasileira de Ciências Agrárias, v. 7, supl., p. 737742, 2012. http://dx.doi.org/10.5039/agraria.v7isa1906

KALAVROUZIOTIS, I. K.; KOUKOULAKIS, P. H.; PAPAIOANNOU, D.; MEHRAC, A. PH and organic matter impact on the indices of soil metal load assessment under wastewater and biosolid reuse. Journal of Chemical Technology \& Biotechnology, v. 93, n. 7, p. 3244-3253, 2018. https://doi.org/10.1002/jctb.5683

KRAMER, D. Israel: A water innovator. Physics Today, v. 69, n. 6, p. 24-26, 2016. https://doi.org/10.1063/PT.3.3193

LAVRNIÉ, L.; ZAPATER-PEREYRA, M.; MANCINI, M. L. Water Scarcity and Wastewater Reuse Standards in Southern Europe: Focus on Agriculture. Water, Air \& Soil Pollution, v. 228, n. 7, p. 1-12, 2017. https://doi.org/10.1007/s11270-017-3425-2

LEUTHER, F.; SCHLÜTER, S.; WALLACH, R.; VOGEL, H.-J. Structure and hydraulic properties in soils under long-term irrigation with treated wastewater, Geoderma, v. 333, p. 90-98, 2019. https://doi.org/10.1016/j.geoderma.2018.07.015

MALAFAIA, G.; ARAÚJO, F. G.; LEANDRO, W. M.; RODRIGUES, A. S. L. Teor de nutrientes em folhas de milho fertilizado com vermicomposto de lodo de curtume e irrigado com água residuária doméstica. Revista Ambiente \& Água, v. 11, n. 4, p. 799 809, 2016. https://dx.doi:10.4136/1980-993X

MAROUELLI, W. A.; SILVA, W. L. C. Irrigação na cultura do pimentão. Brasília: Embrapa, 2012. 20 p.

MEDEIROS, S. S.; GHEYI, H. R.; PÉREZ-MARIN, A. M.; SOARES, F. A. L.; FERNANDES, P. D. Características químicas do solo sob algodoeiro em área que recebeu água residuária da suinocultura. Revista Brasileira de Ciência do Solo, v. 35, n. 03, p. 1047-1055, 2011. http://dx.doi.org/10.1590/S0100-06832011000300038

METCALF, L.; EDDY, H. Wastewater engineering: Treatment and reuse. 2. ed. New York: McGraw Hill, 1991. 1334p.

MONTEIRO, D. R.; SILVA, T. T. S.; SILVA, L. V. B. D.; LIMA, V. L. A.; SANTOS, C. L. M.; PEARSON, E. W. Efeito da aplicação de efluente doméstico tratado nos teores de micronutrientes no solo. Irriga, v. 1, n. 1, p. 40-46, 2014. https://doi.org/10.15809/irriga.2014v1n1p40

MUSAZURA, W.; ODINDO, A. O.; TESFAMARIAM, E. H.; HUGHES, J. C.; BUCKLEY, C. A. Nitrogen and phosphorus dynamics in plants and soil fertigated with decentralised wastewater treatment effluent, Agricultural Water Management, v. 215, p. 55-62, 2019. https://doi.org/10.1016/j.agwat.2019.01.005

OLIVEIRA, P. C. P.; GLOAGUEN, T. V.; ALESSANDRA, R.; GONÇALVES, B.; SANTOS, D. L.; COUTO, C. F. Soil chemistry after irrigation with treated wastewater in semiarid climate. Revista Brasileira de Ciência do Solo, v. 40, 2016. https://dx.doi.org/10.1590/18069657rbcs20140664 
OTENG-PEPRAH, M.; ACHEAMPONG, M. A.; VRIES, N. K. Greywater Characteristics, Treatment Systems, Reuse. Strategies and User Perception - a Review. Water, Air \& Soil Pollution, v. 229, n. 7, p. 229-255, 2018. https://dx.doi.org/10.1007/s11270-0183909-8

PAPAIOANNOU, D; KALAVROUZIOTIS, I. K.; KOUKOULAKIS, P. H.; APADOPOULOS, F.; PSOMA, P. Interrelationships of metal transfer factor under wastewater reuse and soil pollution. Journal of Environmental Management, v. 216, p. 328-336, 2018. https://dx.doi.org/10.1016/j.jenvman.2017.04.008

RAHAV, M.; BRINDT, N.; YERMIYAHU, U.; WALLACH, R. Induced heterogeneity of soil water content and chemical properties by treated wastewater irrigation and its reclamation by freshwater irrigation. Water Resources Research, v. 53, n. 6, p. 4756- 4774, 2017. http://dx.doi.org/10.1002/2016WR019860

RIBEIRO, A. C.; GUIMARÃES, P. T. G.; ALVAREZ, V. H. (ed.). Recomendações para o uso de corretivos e fertilizantes em Minas Gerais, $5^{a}$ aproximação. Viçosa, MG: Comissão de Fertilidade do Solo do Estado de Minas Gerais, 1999. 359 p.

SANDRI, D.; MATSURA, E. E.; TESTEZLAF, R. Alteração química do solo irrigado por aspersão e gotejamento subterrâneo e superficial com água residuária. Engenharia Agrícola e Ambiental, v. 13, n. 6, p. 755-764, 2009. http://dx.doi.org/10.1590/S141543662009000600014

SANDRI, D.; ROSA, R. R. B. Atributos químicos do solo irrigado com efluente de esgoto tratado, fertirrigação convencional e água de poço. Irriga, v. 22, n. 1, p. 18- 33, 2017. http://dx.doi.org/10.15809/irriga.2017v22n1p18-33

SAPKOTA, A. R. Water reuse, food production and public health: Adopting transdisciplinary, systems-based approaches to achieve water and food security in a changing climate.

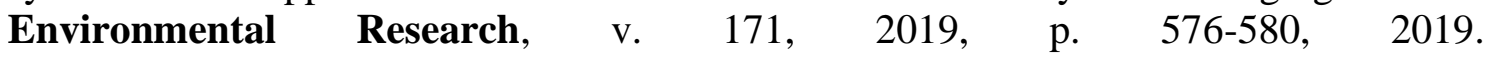
https://doi.org/10.1016/j.envres.2018.11.003

SILVA, F. C. Manual de análises químicas de solos, plantas e fertilizantes. Brasília: Embrapa, 1999. p. 70.

SILVA, L. L.; CARVALHO, C. M.; SOUZA, R. D. P. F.; FEITOSA, H. O.; FEITOSA, S. O.; GOMES FILHO, R. R. Crescimento da pimenta Ekila bode vermelha irrigada com diferentes concentrações de efluente doméstico na água de irrigação. Revista $\begin{array}{llllllll}\text { Agropecuária Técnica, } & \text { v. } 35, \quad \text { n. } & 1, & \text { p. } & 121-132 .\end{array}$ https://doi.org/10.25066/agrotec.v36i1.20954

SILVA, L. V. B. D.; LIMA, V. L. A. de; PEARSON, H. W.; SILVA, T. T. S.; MACIEL S. C. L.; SOFIATTI, V. Chemical properties of a haplustalfs soil under irrigation with treated wastewater and nitrogen fertilization. Revista Brasileira de Engenharia Agrícola e Ambiental, v. 20, n. 4, p. 308-315, 2016. http://dx.doi.org/10.1590/18071929/agriambi.v20n4p308-315

SOIL SURVEY STAFF. Keys to Soil Taxonomy. Washington, DC, 1998.

SOOTHAR, M. K.; BHATTI, S. M.; SALEEM, M.; RAJPAR, I.; DEPAR, N.; SUBHOPOTO, M. Assessment of $\mathrm{K}^{+}, \mathrm{Na}^{+}$and $\mathrm{Cl}^{-}$. Content in Rice Tissues and Soil Irrigated With WastewaterPak. Pakistan Journal of Analytical \& Environmental Chemistry, v. 19, n. 1, p. 64-70, 2018. http://doi.org/10.21743/pjaec/2018.06.06 
SOUSA, J. T; CEBALlOS, B. S. O.; HENRIQUE, I. N.; DANTAS, J. P.; LIMA, S. M. S. Reúso de água residuária na produção de pimentão (Capsicum annuum L.). Revista Brasileira de Engenharia Agrícola e Ambiental, v. 10, n. 1, p. 89- 96, 2006. http://dx.doi.org/10.1590/S1415-43662006000100014

SUN, J.; CHEN, L.; RENE, E. R.; HU, O.; MA, W.; SHEN, Z. Biological nitrogen removal using soil columns for the reuse of reclaimed water: Performance and microbial community analysis. Journal of Environmental Management, v. 217, p. 100-109, 2018 .

TUNC, T.; SAHIN, U. The changes in the physical and hydraulic properties of a loamy soil under irrigation with simpler-reclaimed wastewaters. Agricultural Water Management, v. 158, p. 213-224, 2015. https://doi.org/10.1016/j.agwat.2015.05.012

URBANO, V. R.; MENDONCA, T. G.; BASTOS, R. G.; SOUZA, C. F. Physical-chemical effects of irrigation with treated wastewater on Dusky Red Latosol soil. Revista Ambiente \& Água, v. 10, n. 4, p. 737-747, 2015. http://dx.doi.org/10.4136/ambiagua. 1695

VASUDEVAN, P.; THAPLIYAL, A.; SRIVASTAVA, R. K.; PANDEY, A.; DASTIDAR, M. G.; DAVIES, P. Fertigation potential of domestic wastewater for tree plantations. Journal of Scientific \& Industrial Research, v. 69, p. 146-150, 2010. 